\title{
Long-term variability of winter nitrate concentrations in the Northern Wadden Sea driven by freshwater discharge, decreasing riverine loads and denitrification
}

\author{
Justus E. E. van Beusekom • Sieglinde Weigelt-Krenz • \\ Peter Martens
}

Received: 24 August 2007/Revised: 14 October 2007/ Accepted: 19 November 2007/Published online: 24 November 2007 (C) Springer-Verlag and AWI 2007

\begin{abstract}
The hypothesis of a recent reversal in the eutrophication of the Wadden Sea and the potential of inshore waters in denitrification is explored. Salinity, temperature and nitrate concentrations in the List Tidal Basin (Northern Wadden Sea) have been measured about twice weekly since 1984 . Salinity has a clear seasonal cycle with lowest salinities of about 27 in late winter and highest salinities of about 31 in summer. Mean annual deviations from the long-term mean salinity correlate significantly with riverine freshwater discharge. Winter nitrate concentrations are generally high (about $50 \mu \mathrm{M}$ on average). The major part of the variability is related to salinity $(\sim 35 \%)$. Temperature had a minor impact $(\sim 1 \%)$. Superimposed on this, a long-term decrease of about $1 \mu \mathrm{M}$ per year was found. Together, these processes account for about $45 \%$ of the nitrate variability. The long-term decrease of about $2 \%$ per year is similar to continental riverine trend in total nitrogen loads. In contrast to the List Tidal Basin, salinity explained more than $90 \%$ of nitrate variability in the off-shore German Bight. Salinity (30) normalised winter nitrate data of the German Bight also show a long-term decreasing trend. Most of the List Tidal Basin data are either on or below the nitrate-salinity relation found in the German Bight. This observation suggests that denitrification has a major impact on the
\end{abstract}

Communicated by J. van Beusekom.

J. E. E. van Beusekom ( $\varangle)$ · P. Martens

Alfred Wegener Institute for Polar and Marine Sciences,

Wadden Sea Station Sylt, Hafenstrasse 43,

25992 List/Sylt, Germany

e-mail: justus.van.beusekom@awi.de

S. Weigelt-Krenz

BSH, Bernhard-Nocht-Straße 78, 20359 Hamburg, Germany winter nitrate concentrations in the Northern Wadden Sea compared to the German Bight. It is hypothesised that a large part of the unexplained variability is related to weather-dependent changes in residence time of tidal water masses in the Wadden Sea and circulation patterns within the German Bight.

Keywords Wadden Sea $\cdot$ Salinity $\cdot$ Nitrate . Eutrophication · Denitrification

\section{Introduction}

Nitrogen $(\mathrm{N})$ is a major nutrient limiting eutrophication in many coastal ecosystems (Howarth and Marino 2006). In the North Sea, human activity has increased $\mathrm{N}$ fluxes by a factor of about 8-10 (Van Bennekom and Wetsteijn 1990; Laane et al. 1992; van Beusekom 2005). Eutrophication became evident in the Wadden Sea during the 1970s. De Jonge and Postma (1974) observed an increased import of organic matter from the North Sea into the western Dutch Wadden Sea. The effects of the increased nutrient loads on the Wadden Sea ecosystem became evident during the 1980s. Cadée (1986a, b) observed an increase in primary production and a proliferation of the colony forming flagellate Phaeocystis globosa. The increase in primary production continued until the mid 1990s and since then a decreasing trend is observed (Cadée and Hegeman 2002; Philippart et al. 2007). Especially, the Phaeocystis blooms were considered as negative effects of eutrophication because of the large amounts of foam that were formed after the collapse of these blooms (Lancelot et al. 1987). Other negative effects associated with an increased organic matter load are increased green macroalgae blooms (Reise and Siebert 1994) or the "Black Spot" events in the lower 
saxonian Wadden Sea (Michaelis 1997). In the German Bight (south-eastern North Sea), oxygen depletion events were associated with increased eutrophication (e.g. Gerlach 1984).

During the 1980s measures were taken to combat eutrophication in the European continental water (de Jong 2006). First signs of a decreasing nutrient input were observed for phosphorus (e.g. Van Bennekom and Wetsteijn 1990) but this had no apparent effect on the primary production levels that remained high (Cadée and Hegeman 1993).

The Wadden Sea interacts with the North Sea on a much larger scale than its areal share. Early investigations already indicated that the high secondary production of the Wadden Sea could only be explained by the import of organic matter from the North Sea (Verwey 1952). This aspect was further elaborated by Postma $(1954,1981)$ and van Straaten and Kuenen (1957, 1958). Postma (1984) postulated a "line of no return". Suspended particles within a distance of about $40 \mathrm{~km}$ from the Wadden Sea have a high probability to be transported towards the coast and to accumulate in the Wadden Sea. Gravitation circulation is involved in transporting particles with a coastward bottom current towards the Wadden Sea (e.g. Giessen et al. 1990; de Jonge and de Jong 2002) while particles beyond that line will be transported away from the Wadden Sea with the residual currents. The nitrogen biogeochemistry of the North Sea may also be significantly influenced by the Wadden Sea on a much larger scale than its areal share. Shelf sediments are important sites for denitrification, a process that transforms nitrate to nitrogen gas (Howarth et al. 1996; Seitzinger and Giblin 1996) and part of the accumulated particulate organic nitrogen may be removed by denitrification after remineralisation. A part of nitrate in the water column may also be removed by denitrification. Given an average salinity in the Wadden Sea of about 28, a large proportion of the nitrate is assumed to be from riverine sources. As most of the continental run off flows along the Wadden Sea towards the north, we suggest that the Wadden Sea may remove a substantial amount of the riverine nitrogen by denitrification.

A recent evaluation of the riverine total nitrogen (TN) loads into the Wadden Sea and adjacent North Sea shows a decreasing trend, while Wadden Sea time series revealed no clear temporal trend in salinity normalised winter nitrate concentrations (van Beusekom et al. 2005a). In this paper we analyse winter nitrate data in the List Tidal Basin from 1984 to 2005 in more detail. We will prove that a decreasing trend does indeed exist in parallel with a decreasing riverine TN input. A comparison with regular observations of the nitrate distribution in the German Bight during winter reveals that in the Wadden Sea nitrate is lower than expected based on salinity. This suggests a major impact of denitrification on nitrate levels in the Wadden Sea.

\section{Materials and Methods}

Area description

Study site

The study was conducted in the List Tidal Basin $\left(54^{\circ} 50^{\prime}-\right.$ $55^{\circ} 10^{\prime} \mathrm{N}$ and $8^{\circ} 20^{\prime}-8^{\circ} 40^{\prime} \mathrm{E}$ ), a $404 \mathrm{~km}^{2}$ semi-enclosed bight in the Northern Wadden Sea (North Sea, Europe). The basin is connected to the open North Sea by a single tidal inlet (Fig. 1). To the north and to the south, the basin is closed by two dams connecting the Island of Rømø and the Island of Sylt to the mainland. Eastwards, the basin is closed by the mainland. Water volume at mean tidal level is about $845 \times 10^{6} \mathrm{~m}^{3}$. The mean water depth is $2.7 \mathrm{~m}$ (Loebl et al. 2007) but reaches up to $40 \mathrm{~m}$ in the main tidal channel. The water column is mostly homogenously mixed. Tides are semi-diurnal; the mean tidal range is about $2 \mathrm{~m}$. During low tide, about $40 \%$ of the area is emerged. About $90 \%$ of the area is covered by sandy sediments. Salinity ranges between 24 in late winter and 32 in august, temperature between $-1{ }^{\circ} \mathrm{C}$ in winter and $22^{\circ} \mathrm{C}$ in summer. Suspended matter ranges between 20 and $60 \mathrm{mg} / \mathrm{L}$ in winter to $\sim 5 \mathrm{mg} / \mathrm{L}$ in late summer. A detailed description of the area is given by Gätje and Reise (1998).

\section{Seawater sampling and analysis}

Water was sampled twice a week by ship at two nearby stations (St 1: $55^{\circ} 01.3 \mathrm{~N}, 8^{\circ} 27.1 \mathrm{E} ;$ St $4: 55^{\circ} 2.26 \mathrm{~N}, 8^{\circ} 26.3 \mathrm{E}$ ) from $1 \mathrm{~m}$ depth, using a $5 \mathrm{~L}$ Niskin bottle or a TPN Sampler. The stations represent two distinct conditions in the basin; the deep main channel and the shallow subtidal. Where indicated, monthly means were calculated, otherwise the individual data were used. Station 1 is situated in the southernmost of three major tidal channels, station 4 is situated in a small tidal channel draining Königshafen, a small tidal bay in the north of the Island Sylt. The latter station cannot be sampled at very low tides. In case the ship was not available, samples were taken from a nearby jetty. Temperature was measured with a reversing thermometer fixed to the bottle. Salinity was measured with a salinometer (Autosal 8400). In case the nutrients were not analysed immediately, the samples were stored at $-20^{\circ} \mathrm{C}$ and for silicate at $4^{\circ} \mathrm{C}$. Nutrients were analysed according to Grasshoff et al. (1983). Prior to February 1999 unfiltered samples were analysed, after February 1999 seawater was filtered through $0.47 \mu \mathrm{m}$ pore size Nuclepore filters. 
Fig. 1 Map of the List Tidal Basin showing the position of the two sampling stations (1 and 4). Tidal flats are dotted. The broken line indicates the $5 \mathrm{~m}$ depth line

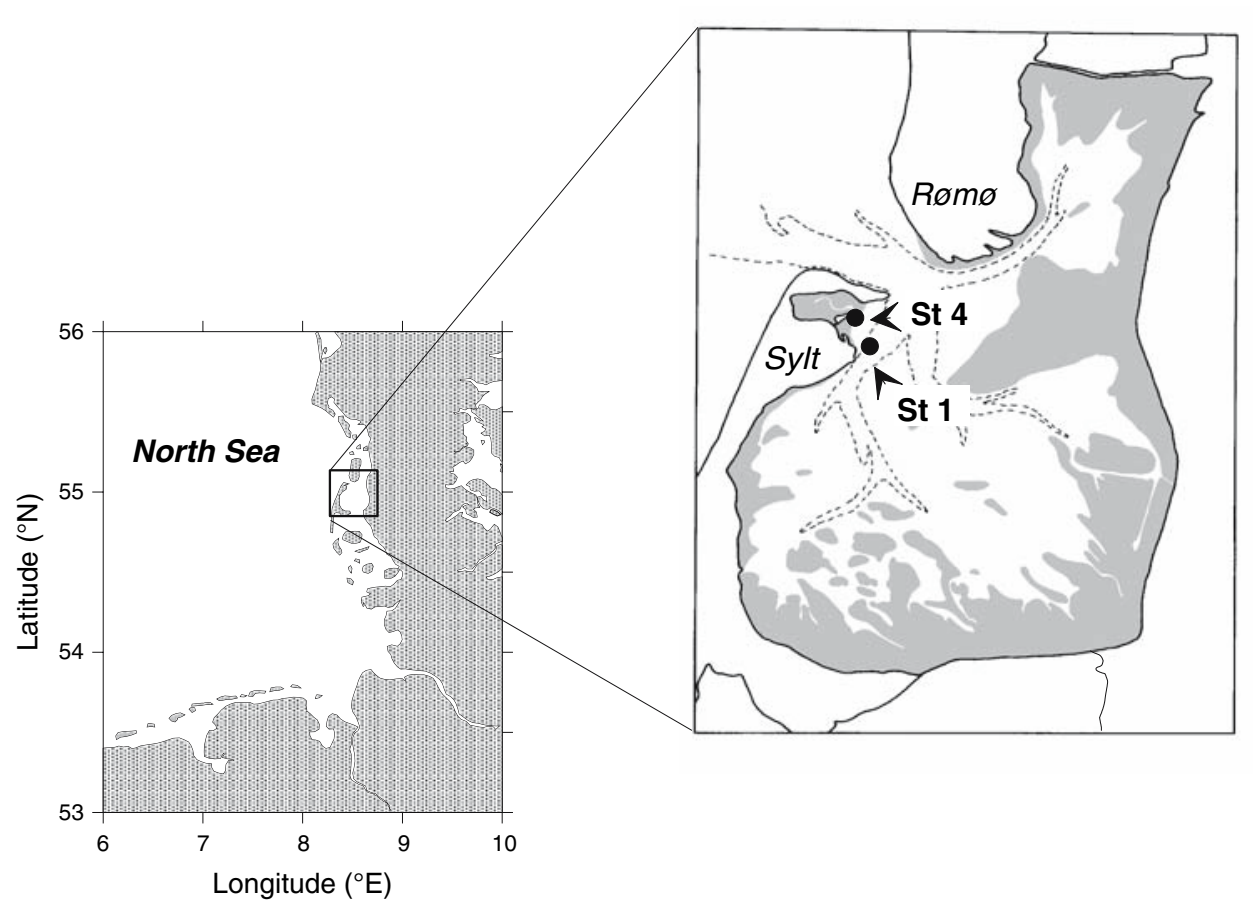

\section{Quality control}

From 1995 to 2002 the lab participated in quality control exercises for nutrient analysis. Before 1997 and from 1999 onwards our nitrate values were in excellent agreement with the attributed concentrations but between mid-1997 and 1999, the reported values were below the attributed values indicating analytical problems during that period. We basically used the raw data, but checked whether the outcome of our results was strongly influenced by the 1997-1999 data.

\section{Results}

\section{Salinity}

Figure 2 presents a contour plot of mean monthly salinity in the List Tidal Basin from 1984 to 2005. Salinity shows a clear seasonal cycle with maximum values of about 32 during summer and minimum values of about 24 during late winter. Based on deviations of mean monthly values from the long term monthly mean, mean annual deviations were calculated. The interannual variation of the mean annual deviations shows a similar pattern as the mean annual fresh water discharge from the rivers Elbe and Weser (Fig. 3a) explaining about $70 \%$ of the interannual variation (Fig. 3b). A similar correlation was found with the freshwater discharge from the rivers Rhine and Maas $\left(R^{2}=0.716 ; n=19\right)$. These results suggest that the major part of the variability in salinity in the List Tidal Basin is determined by riverine fresh water discharges into the southeastern North Sea.
Interannual variation in nitrate concentrations

Figure 4 presents a contour plot of the monthly nitrate concentration in the List Tidal Basin. A clear seasonal cycle is present with maximum values of about $30-60 \mu \mathrm{M}$ during late winter and minimum values reaching below $1 \mu \mathrm{M}$ during July and August. Values often reached

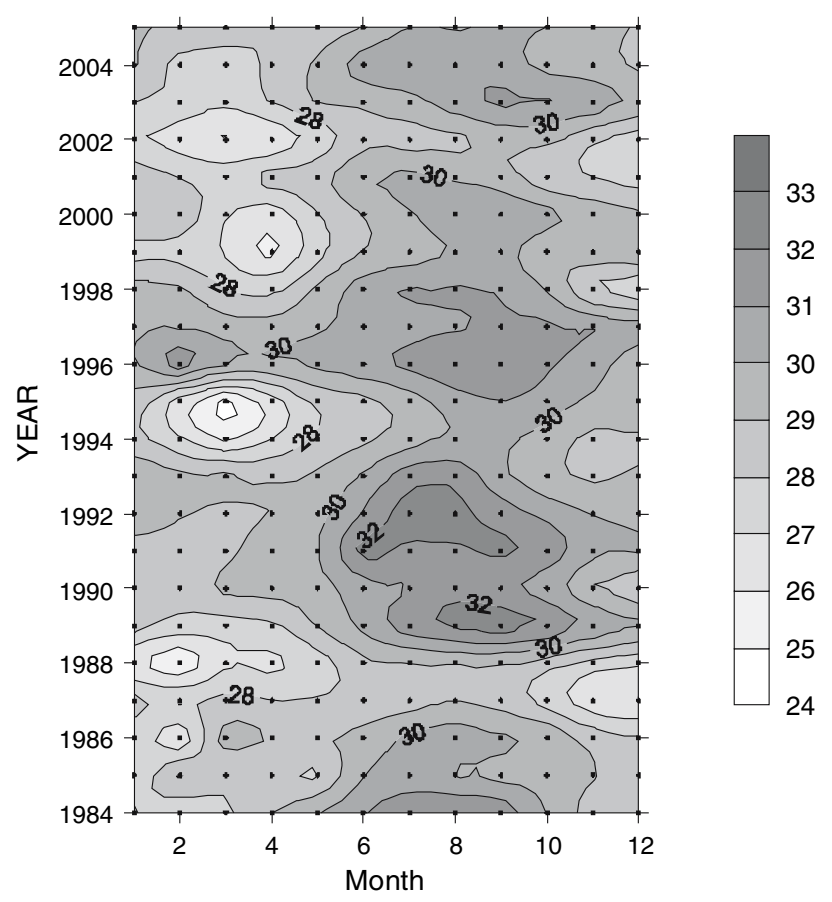

Fig. 2 Contour plot of mean monthly salinity in the List Tidal Basin from 1984 to 2005 

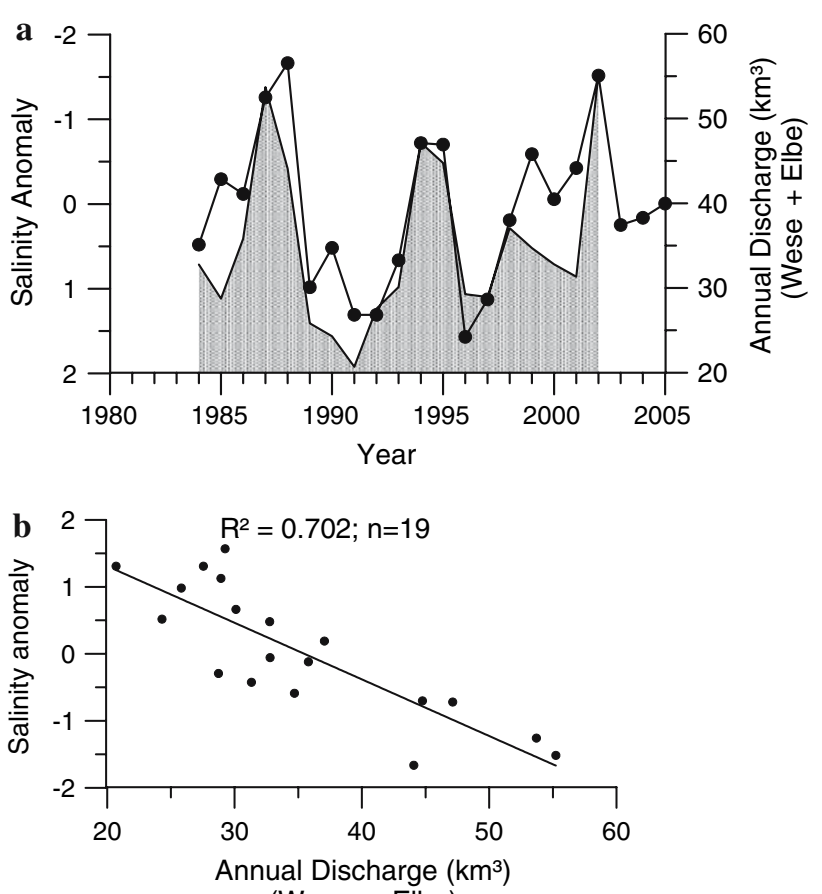

(Weser + Elbe)

Fig. 3 a Annual average salinity anomaly (Solid line and dots; based on the deviation from the mean monthly salinity) from 1984 to 2005 in the List Tidal Basin and the mean annual riverine discharge 19842002 of the rivers Elbe plus Weser (hatched area). b Correlation between annual freshwater discharge by the rivers Elbe plus Weser and the salinity anomaly in the List Tidal Basin

detection limit $(<0.1 \mu \mathrm{M})$ around August. Three trends are suggested by comparing the salinity and nitrate contour plots: firstly, years with lower than average salinity have higher winter nitrate concentrations than years with higher than average salinity. Secondly, highest winter concentrations are observed during the first half of the observation period and thirdly, summer concentrations generally decrease. Focus of the present data analysis will be on the winter concentrations. In a companion paper (Loebl et al. 2008) the summer data will be analysed in relation to longterm shifts in nutrient limitation.

We analysed for all winter samples (1984-2005), the relation between nitrate and salinity. Data from January to March were used, excluding those observations where high chlorophyll values $(>8 \mu \mathrm{g} / \mathrm{L})$ indicate a possible interference by winter diatom blooms. Such blooms may occur in cold winters from late February onwards (Martens 2001). Winter nitrate concentrations significantly correlated with salinity explaining about one third of the variability (Fig. $5 ; R^{2}=0.34 ; P \gg 0.0001$ ). Temperature may have a positive effect on remineralisation rates and thus on nitrate concentrations. We analysed the effect of salinity and temperature on the nitrate concentrations with a multiple regression. Both factors had a significant effect on the nitrate concentration (salinity $P \ll 0.000$; temperature

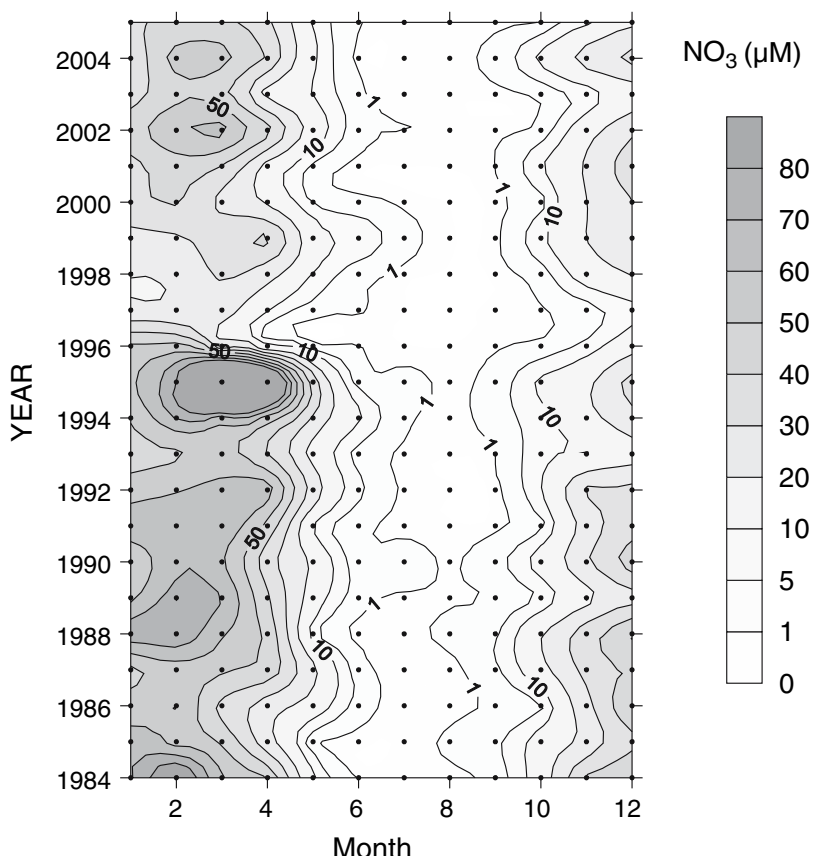

Fig. 4 Contour plot of mean monthly nitrate concentrations from 1984 to 2005 in the List Tidal Basin. Values from mid 1997 to early 1999 may be underestimated

$p=0.0001)$ but the amount of explained variability was hardly increased (to $R^{2}=0.36$ ). The residual correlates significantly with time showing a decreasing trend of $1.28 \mu \mathrm{M}$ per year (Fig. 6). Given a mean nitrate concentration of about $55 \mu \mathrm{M}$ (van Beusekom 2006) implies a decrease of about $2 \%$ per year which is similar to the decreasing trend of about $2 \%$ observed in continental rivers influencing the Wadden Sea (van Beusekom et al. 2005a). These results imply that the reduction in riverine TN load entails lower nitrate concentrations during winter in the List Tidal Basin. The three factors salinity, temperature and time explain only about $43 \%$ of the $\mathrm{NO}_{3}$ variability in winter. The anomalous year 1995 or the underestimation of $\mathrm{NO}_{3}$ during the years 1997-1999 contribute little to the overall variability. Correcting for the underestimation increases the explained variability to $45 \%$, excluding the 1995 values increases the explained variability to $51 \%$.

Thus, the factors time, salinity and temperature explain about half of the observed variability. One possible explanation is that local processes like denitrification or remineralisation are responsible for a large part of the variability. We tested this by comparing the nitrate-salinity relation observed in the List Tidal Basin with regular winter $\mathrm{NO}_{3}$ observations from the German Bight. The latter observations are part of a federal monitoring programme carried out by the BSH (Federal Maritime and Hydrographic Agency). In general, $\mathrm{NO}_{3}$ values in the 


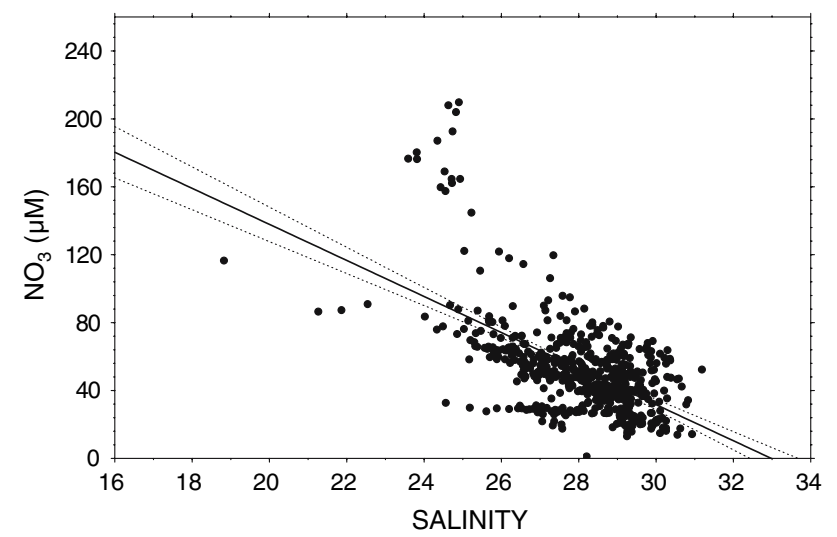

Fig. 5 Salinity-nitrate relation for winter values (January-March) from 1995 to 2005 excluding samples with a chlorophyll $a$ concentration higher than $8 \mu \mathrm{g} / \mathrm{L}$

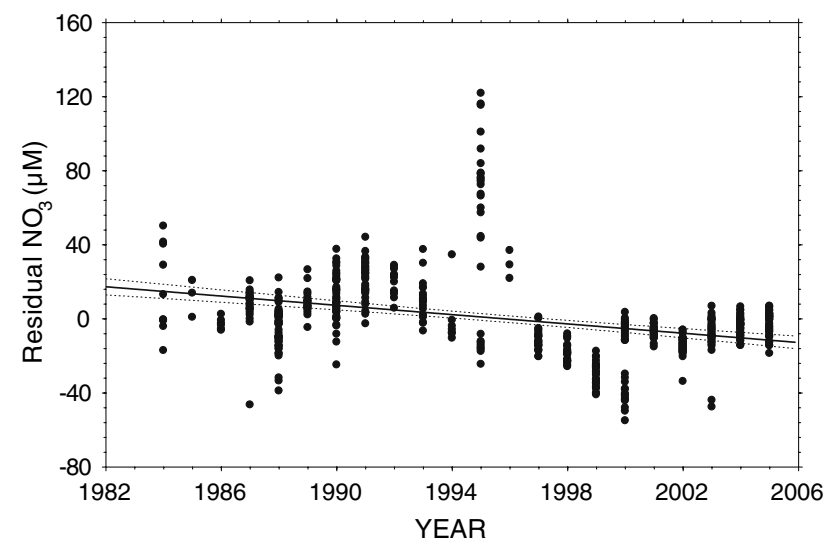

Fig. 6 Long-term trend of nitrate in winter. The residual after a multiple regression with salinity and temperature is shown

German Bight are strongly correlated with salinity $\left(R^{2}>0.95\right)$ in winter. In the List Tidal Basin, we expect $\mathrm{NO}_{3}$ values above the German Bight nitrate-salinity regression line if remineralisation dominates. We expect values below the German Bight nitrate-salinity regression line if denitrification dominates. In Fig. 7 we compare the salinity and nitrate data from the List Tidal Basin for the years 2000-2005 with the salinity and nitrate data observed during February/March 2004 in the German Bight. In contrast to the large scatter in a salinity-nitrate plot of the Wadden Sea data, the German Bight nitrate data are extremely well correlated with salinity $\left(R^{2}=0.96\right)$. Most data from the List Tidal Basin are below the German Bight nitrate-salinity regression line suggesting that removal processes like denitrification have a strong impact on the local $\mathrm{NO}_{3}$ levels. Figure 8 presents a nitrate-salinity plot of all List Tidal Basin winter data. Before the year 2000 maximum concentrations were higher than after.

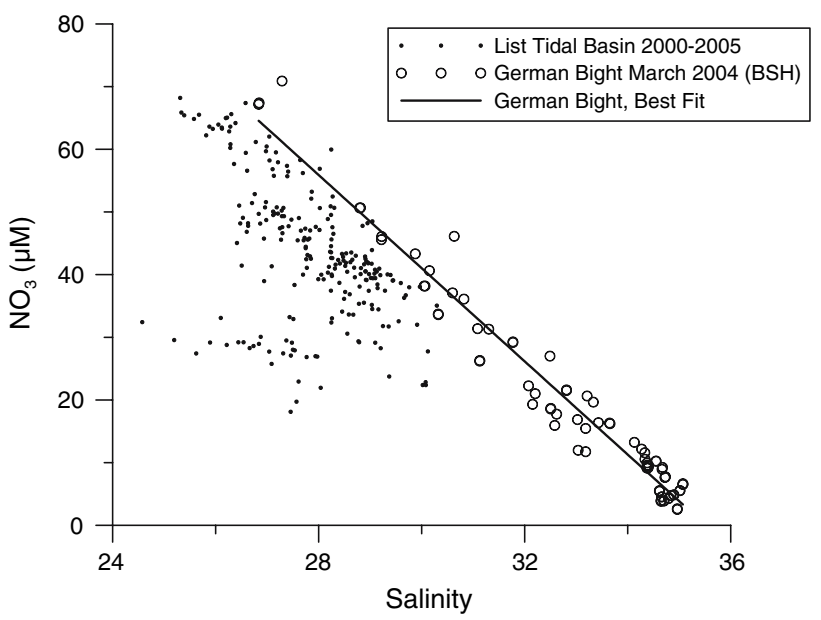

Fig. 7 Comparison of the nitrate-salinity relation in the German Bight in 2004 with the nitrate-salinity relation in the List Tidal Basin during 2000-2005

Except for a few values around a salinity of 24, the maximum concentrations were similar to the salinitynitrate regression line observed in the German Bight in winter 1989. This year was characterised by maximum slope of the nitrate-salinity regression line (Körner and Weichart 1992; van Beusekom et al. 2005b). The extreme nitrate values around a salinity of 24 were confined to a short period in 1995 and also before the year 2000, variability was high and most values were lower than expected on the basis of the nitrate-salinity relation observed in 1989.

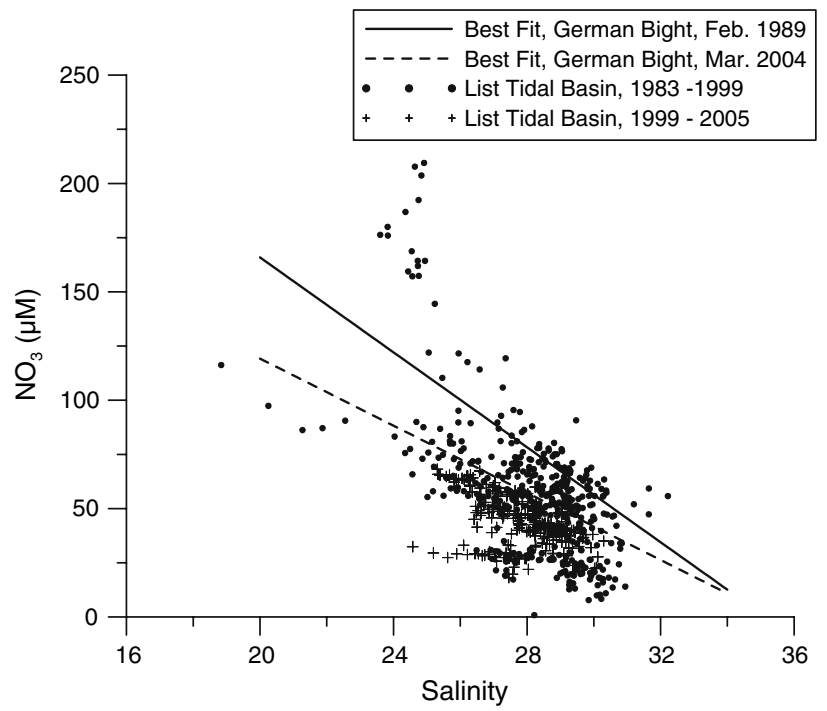

Fig. 8 Comparison of all winter nitrate and salinity data from the List Tidal Basin with the nitrate-salinity relations observed in the German Bight during 2004 (compare Fig. 7) and 1989 


\section{Discussion}

Decreasing nitrate trend in winter in the Northern Wadden Sea

Until the end of the 1990s no clear trend in riverine TN concentrations and loads into the North Sea was evident (e.g. Brion et al. 2004). Most of the observed variability in loads was related to freshwater discharge. A more recent analysis of input data from rivers debouching into the Wadden Sea reveals a decreasing trend of about $2 \%$ per year since the mid-1980s. The trend was based on total annual nitrogen load divided by the annual freshwater discharge (van Beusekom et al. 2005a). Philippart et al. (2007) also noted a decreasing trend in TN load of the IJsselmeer (a branch of the Rhine delta) into the Western Wadden Sea. However, whether the trends in riverine discharge influenced local nitrogen concentrations within the Wadden Sea remained elusive. Van Beusekom et al. (2005a) did not find a clear trend in salinity normalised nitrate concentrations from the Wadden Sea. The present study reveals for the first time a decreasing trend of winterly nitrate concentrations in the Northern Wadden Sea. The mean decreasing trend is about $1.3 \mu \mathrm{M}$ or $2 \%$ per year given mean winter concentrations of about $55 \mu \mathrm{M}$ (van Beusekom 2006) and implies a trend being in the same range as the long-term decreasing trend of riverine $\mathrm{TN}$ load.

The possible impact of denitrification on nitrate levels in winter

At least four factors contribute to the observed variability in winterly nitrate concentrations, (1) salinity, (2) temperature, (3) trends in riverine $\mathrm{TN}$ input and (4) an unknown loss factor. The first three factors explain at best about $45 \%$ of the observed variability and about $55 \%$ remains unexplained. We suggest that denitrification (reduction of $\mathrm{NO}_{3}$ to gaseous $\mathrm{N}_{2}$ ) and Anammox (the anaerobic oxidation of ammonium with nitrite to gaseous $\mathrm{N}_{2}$ ) (Kuypers et al. 2003) are major processes adding to the observed variability. Most of the explained variability is due to salinity $(\sim 35 \%)$ followed by a decreasing trend ( $\sim 9 \%)$. Temperature has a significant effect but explains only a small part of the observed variability. The good correlation between salinity anomalies (deviations from the long-term mean) and freshwater discharge suggests that salinity is a good proxy for river water influence. Thus the correlation between nitrate and salinity reflects the response to riverine nitrogen load into the Wadden Sea. Note that nitrate dominates by far the riverine nitrogen load.
As mentioned above, a large part of the winter nitrate variability is yet unexplained. We suggest that denitrification and possibly anammox adds to the observed variability. This suggestion is based on two facts. Firstly, budget calculations show that the nitrogen loss is significant. Secondly, the nitrate concentrations observed in the List Tidal Basin are generally lower than expected on the basis of salinity-nitrate correlations in the adjacent German Bight.

Recently, it has become evident that removal of nitrogen by denitrification or Anammox is playing a major role in the coastal nitrogen cycle. Based on nitrate-salinity relations in the North Sea, Hydes et al. (1999) concluded that the North Sea is a sink for nitrogen: denitrification removes some amount of nitrogen from the North Sea that exceeds riverine and atmospheric input. The importance of denitrification as a nitrogen sink fits with model calculations (Smith et al. 1997). Seitzinger and Giblin (1996) estimated for North Atlantic shelf sediments that approximately $13 \%$ of the nitrogen taken up by phytoplankton was denitrified. Budget calculations for the German Bight revealed an imbalanced nitrogen budget (Beddig et al. 1997). The imbalance was probably due to an underestimation of the used denitrification rates (van Beusekom et al. 1999). Indeed, recent progress in the methodology of denitrification measurements show that early methods like the acetylene blocking method underestimate denitrification rates (van Luijn et al. 1996; Lohse et al. 1996; van Beusekom et al. 1999). Based on available measurements and budgets, van Beusekom estimated an annual denitrification rate of about $600 \mathrm{mmol} \mathrm{m}^{-2}$ per year for the Wadden Sea.

Nitrate concentrations in the List Tidal Basin were generally about $10-20 \mu \mathrm{M}$ lower than expected on the basis of salinity and the observed nitrate-salinity relation in the adjacent German Bight (Figs. 7, 8). But occasionally, much lower values ( 30-40 $\mu \mathrm{M}$ below expected values) were observed. These lower than expected concentrations suggest that a significant part of the nitrate is removed. Possible processes are denitrification (e.g. Jensen et al. 1996) and Anammox (Kuypers et al. 2003).

In the following, we will explore whether and under which conditions denitrification can remove enough nitrate to explain the $10-40 \mu \mathrm{M}$ lower concentrations as observed in the German Bight outside the Wadden Sea. We will use the above mentioned denitrification rate of $600 \mathrm{mmol} \mathrm{m}^{-2}$ per year but note that more measurements with new methods preferably with the $\mathrm{N}_{2} / \mathrm{Ar}$ method (e.g. Kana et al. 1994) are needed for a better estimate. Given the above rate and a mean depth of the List Tidal Basin of about $2.7 \mathrm{~m}$, denitrification can potentially reduce the ambient nitrate concentrations by $0.6 \mu \mathrm{M}$ per day. This would imply that at ambient levels of about $50 \mu \mathrm{M}$ concentrations could be halved within 40 days. This will never happen in reality as 
the Wadden Sea continuously exchanges water masses with the North Sea. Two extreme situations will be compared: (1) an exchange of the List Tidal Basin with the North Sea without any significant input of Wadden Sea water that is transported northwards with the residual current and (2) no exchange with the open North Sea and only exchange with Wadden Sea water flowing in from the south.

If the List Tidal Basin would only exchange with the North Sea and the North Sea nitrate concentrations are kept constant (which is reasonable given its size and depth), equilibrium will establish that is determined by the exchange rate and the denitrification rate. Reasonable exchange rates for the List Tidal Basin are in the order of 0.1 per day (Fast et al. 1999). Given initial nitrate levels of $50 \mu \mathrm{M}$ and the removal of $0.6 \mu \mathrm{M}$ per day by denitrification, equilibrium will be established after about 50 days at $44 \mu \mathrm{M}$ (daily supply from the North Sea is 0.1 times the concentration difference between North Sea and Wadden Sea and is equal to the removal by denitrification). The concentration difference between the North Sea and the Wadden Sea will increase proportional to higher denitrification rates and inversely proportional with lower exchange rates. Large differences in the order of 20-30 $\mu \mathrm{M}$ are therefore only possible if extreme high denitrification rates or extreme low exchange rates are assumed.

If the exchange between the North Sea and Wadden Sea is limited and the List Tidal Basin would only exchange with Wadden Sea water coming from the south with the residual currents, much lower nitrate values can be expected. Residual currents in the German Bight are mostly directed northward (e.g. Otto et al. 1990). It will take a parcel of water originating from the mouth of the Elbe river about one month to reach the List Tidal Basin (residual current velocity $\sim 5 \mathrm{~cm} / \mathrm{s}$ (Hickel 1980). If exchange between the Wadden Sea and the North Sea is low, even longer transport times are possible due to the residence within each tidal basin. Given this, the factual residence time within the Wadden Sea can be in the order of several weeks and denitrification is able to exert a maximum impact on the $\mathrm{NO}_{3}$ concentrations. Values in the order of $20-40 \mu \mathrm{M}$ below the value expected on the basis of the salinity should be possible.

Of course, the above estimates are very rough. However, they highlight that the prevailing hydrography potentially has a large impact on the deviation of nitrate values in the List Tidal Basin. We therefore hypothesise, that a large part of the unexplained variability in the nitrate concentrations in winter in the List Tidal Basin is related to two factors (1) wind induced differences in residence time within the Wadden Sea and interannual changes in the circulation pattern of the German Bight. Further studies are needed to constrain the denitrification rates in winter and to assess the relative importance of Anammox.
Implications for coastal management and monitoring

Winter concentrations are often used as indicators of the eutrophication status (e.g. Frtebjerg et al. 2003) as during this season biological processes are at a minimum (Van Bennekom and Wetsteijn 1990). Indeed, good spatial correlations are found in the North Sea between annual primary production and winter nitrate concentrations (e.g. van Beusekom and Diel-Christiansen 1994; de Vries et al. 1998; Hydes et al. 1999). However, due to the potentially large influence of denitrification, nitrate is a less useful indicator of the eutrophication status in shallow coastal areas. This situation is aggravated in the Wadden Sea where not only local primary production but also the import of primary produced organic matter from off-shore areas outside the Wadden Sea proper determines the eutrophication status (van Beusekom and de Jonge 2002). Nitrite and ammonium values during autumn and chlorophyll levels during summer may be better eutrophication indicators as they show good correlations with riverine $\mathrm{TN}$ discharge (van Beusekom et al. 2001, 2005a)

The difficulty in identifying a decreasing trend in winterly nitrate concentrations contrasts with a clear decrease in phosphate concentrations in the Wadden Sea that was already observed during the 1990s (de Jonge et al. 1996; Cadée and Hegeman 1993). The reason for this discrepancy may be two-fold. On one hand, riverine total phosphorus loads show a stronger declining trend of about $3 \%$ per year as compared to TN loads ( $\sim 2 \%$ per year; van Beusekom et al. 2005). On the other hand, denitrification may add to the observed variability by removing an unknown and variable part of the nitrate stock.

Acknowledgments The authors thank the Captain and crew of "Mya" for their help with sampling and the late Conny Reinecke, Alexandra Halbe, Ludmila Baumann and Tatyana Romanova for analytical support. Comments by Karsten Reise and Victor de Jonge are gratefully acknowledged.

\section{References}

Ærtebjerg G, Andersen JH, Hansen OS (2003) Nutrients and eutrophication in Danish marine waters. A challenge for science and management. National Environmental Research Institute. $126 \mathrm{pp}$

Beddig S, Brockmann U, Dannecker W, Körner D, Pohlmann T, Puls W (1997) Nitrogen fluxes in the German Bight. Mar Pollut Bull 34:382-394

Brion N, Baeyens W, de Galan S, Elskens M, Laane RWPM (2004) The North Sea: source or sink for nitrogen and phosphorus to the Atlantic Ocean? Biogeochemistry 38:277-296

Cadée GC (1986a) Increased phytoplankton primary production in the Marsdiep area (Western Dutch Wadden Sea). Neth J Sea Res 20:285-290 
Cadée GC (1986b) Recurrent and changing seasonal patterns in phytoplankton of the westernmost inlet of the Dutch Wadden Sea from 1969 to 1985. Mar Biol 93:281-289

Cadée GC, Hegeman J (1993) Persisting high levels of primary production at declining phosphate concentrations in the Dutch coastal area (Marsdiep). Neth J Sea Res 31:147-152

Cadée GC, Hegeman J (2002) Phytoplankton in the Marsdiep at the end of the 20th century; 30 years monitoring biomass, primary production, and Phaeocystis blooms. J Sea Res 48:97-110

De Jong F (2006) Marine eutrophication in perspective. On the relevance of ecology for environmental policy. Springer, Berlin

De Jonge VN, Postma H (1974) Phosphorus compounds in the Dutch Wadden Sea. Neth J Sea Res 8:139-153

De Jonge VN, Bakker JF, Stralen M, van (1996) Recent changes in the contributions of river Rhine and North Sea to the eutrophication of the Western Dutch Wadden Sea. Neth J Aquat Ecol 30:27-39

De Jonge VN, de Jong DJ (2002) 'Global change' impact of interannual variation in water discharge as a driving factor to dredging and spoil disposal in the river Rhine system and of turbidity in the Wadden Sea. Est Coast Shelf Sci 55:969-991

De Vries I, Duin NM, Peeters JCH, Los FJ, Bokhorst M, Laane RPWM (1998) Patterns and trends in nutrients and phytoplankton in Dutch coastal waters: comparison of time-series analysis, ecological model simulation, and mesocosm experiments. ICES J Mar Sci 55:620

Fast T, Müller A, Wilhelm A (1999) The Sylt Romo Bight Ecosystem Model (SRB Model)—an introduction, GKSS Report 99/E/28, $101 \mathrm{pp}$

Gätje C, Reise K (eds) (1998) Ökosystem Wattenmeer: Austausch, Transport und Stoffwandlungsprozesse. Springer, Heidelberg

Gerlach SA (1984) Oxygen depletion 1980-1983 in coastal waters of the Federal Republic of Germany. First Report of the working group "Eutrophication of the North Sea and the Baltic"

Grasshoff K, Erhardt M, Kremling K (1983) Methods of seawater analysis. Verlag Chemie, Weinheim

Hickel W (1980) The influence of Elbe river water on the Wadden Sea of Sylt (German Bight, North Sea). Dtsch Hydrographische Z 33:42-53

Howarth RW, Marino R (2006) Nitrogen as the limiting nutrient for eutrophication in coastal marine ecosystems: evolving views over three decades. Limnol Oceanogr:364-376

Howarth RW, Billén G, Swaney D, Townsend A, Jaworski N, Lajtha K, Downing JA, Elmgren R, Caraco N, Jordan T, Berendse F, Freney J, Kudeyarov V, Murdoch P, Zhao-Liang Z (1996) Regional nitrogen budgets and riverine $\mathrm{N} \& \mathrm{P}$ fluxes for the drainages to the North Atlantic Ocean: natural and human influences. Biogeochemistry 35:141-180

Hydes DJ, Kelly-Gerreyn BA, Le Gall AC, Proctor R (1999) The balance of supply of nutrients and demands of biological production and denitrification in a temperate latitude shelf seaa treatment of the southern North Sea as an extended estuary. Mar Chem 68:117-131

Jensen KM, Jensen MH, Kristensen E (1996) Nitrification and denitrification in Wadden Sea sediments (Königshafen, Island of Sylt, Germany) as measured by nitrogen isotope pairing and isotope dilution. Aquat Microb Ecol 11:181-191

Kana TM, Darkangelo C, Hunt MD, Oldham JB, Bennett GE, Cornwell JC (1994) Membrane inlet mass spectrometer for rapid high-precision determination of $\mathrm{N}_{2}, \mathrm{O}_{2}$ and $\mathrm{Ar}$ in environmental water samples. Anal Chem 66:4166-4170

Körner D, Weichart G (1992) Nutrients in the German Bight: concentrations and trends. ICES Mar Sci Symp 195:159-176

Kuypers MMM, Sliekers AO, Lavik G, Schmid M, Jørgensen BB, Kuenen JG, Sinninghe Damsté JS, Strous M, Jetten MSM (2003)
Anaerobic ammonium oxidation by anammox bacteria in the Black Sea. Nature 422:608-611

Laane RWPM (1992) Background concentrations of natural compounds. Report No. Report DGW-92.033, Ministry of Transport, Public Works and Water Management, Hague

Lancelot C, Billen G, Sournia A, Weisse T, Colijn F, Davies MJW, Wassman P (1987) Phaeocystis blooms and nutrient enrichment in the continental coastal zones of the North Sea. Ambio 16:3846

Loebl M, Dolch T, van Beusekom JEE (2007) Annual dynamics of pelagic primary production and respiration in a shallow coastal basin. J Sea Res. doi:10.1016/j.seares.2007.06.003

Loebl M, Colijn F, van Beusekom JEE (2008) Increasing nitrogen limitation during summer in the List Tidal Basin (Northern Wadden Sea). Helgoland Mar Res. 62

Lohse L, Kloosterhuis HT, van Raaphorst W, Helder W (1996) Denitrification rates as measured by the isotope pairing method and by the acetylene inhibition technique in continental shelf sediments of the North Sea. Mar Ecol Prog Ser 132:169-179

Martens P (2001) Effects of the severe winter 1995/96 on the biological oceanography of the Sylt-Røm $\varnothing$ tidal basin. Helgoland Mar Res 55:166-169

Michaelis H (1997) History and distribution of black spots in the east Frisian Wadden Sea. In: Henke S (ed) Black spots in the Wadden Sea. Federal Environmental Agency, Berlin, pp 13-17

Otto L, Zimmerman J, Furnes G, Mork M, Saetre R, Becker G (1990) Review of the physical oceanography of the North Sea. Neth J Sea Res 26:161-238

Philippart CJM, Beukema JJ, Cadée GC, Dekker R, Goedhart PW, van Iperen JM, Leopold MF, Herman PMJ (2007) Impact of nutrients on coastal communities. Ecosystems 10:95-118

Postma H (1954) Hydrography of the Dutch Wadden Sea. Arch néerl Zool 10:405-511

Postma H (1981) Exchange of materials between the North Sea and the Wadden Sea. Mar Geol 40:199-215

Postma H (1984) Introduction to the symposium on organic matter in the Wadden Sea. Neth Inst Sea Res Pub Ser 10:13-22

Reise K, Siebert I (1994) Mass occurrence of green algae in the German Wadden Sea. Dtsch Hydrographische Z 1:171-188

Seitzinger SP, Giblin AE (1996) Estimating denitrification in North Atlantic continental shelf sediments. Biogeochemistry 35:235260

Smith SV, Boudreau PR, Ruardij P (1997) NP budget for the Southern North Sea. http://data.ecology.su.se/MNODE/Europe/NORTHSEA. HTM

Van Bennekom AJ, Wetsteijn FJ (1990) The winter distribution of nutrients in the southern bight of the North Sea (1961-1978) and in the estuaries of the Scheldt and the Rhine/Meuse. Neth J Sea Res 25:75-87

Van Beusekom JEE (2005) A historic perspective on Wadden Sea eutrophication. Helgoland Mar Res 59:45-54

Van Beusekom JEE (2006) Eutrophication proxies in the Wadden Sea: Regional differences and background concentrations. DMU Technical Reports 573:45-51

Van Beusekom JEE, Diel-Christiansen S (1994) A synthesis of phytoand zooplankton dynamics in the North Sea environment. WWF, Godalming

Van Beusekom JEE, de Jonge VN (2002) Long-term changes in Wadden Sea nutrient cycles: importance of organic matter import from the North Sea. Hydrobiologia 475/476:185-194

Van Beusekom JEE, Brockmann UH, Hesse KJ, Hickel W, Poremba K, Tillmann U (1999) The importance of sediments in the transformation and turnover of nutrients and organic matter in the Wadden Sea and German Bight. Ger J Hydrogr $51: 245-266$ 
Van Beusekom JEE, Fock H, de Jong F, Diel-Christiansen S, Christiansen B (2001) Wadden Sea specific eutrophication criteria. Wadden Sea Ecosyst 14:1-115

Van Beusekom JEE, Bot PVM, Goebel JHM, Lenhart H, Pätsch J, Peperzak L, Petenati T, Reise K (2005a) Eutrophication. In: Essink K, Dettmann C, Farke H, Laursen K, Lüerßen G, Marencic H, Wiersinga W (eds) Wadden Sea quality status report 2004. Wadden Sea Secretariat, Wilhelmshaven, pp 141154

Van Beusekom JEE, Elbrächter M, Gaul H, Goebel JHM, Hanslik M, Petenati T, Wiltshire KH (2005b) Nährstoffe. In: Messprogramm Meeresumwelt: Zustandsbericht für Nordsee und Ostsee 1999_ 2002, Bundesamt für Seeschifffahrt und Hydrographie, Hamburg, pp 25-32
Van der Giessen A, de Ruijter WPM, Borst JC (1990) Threedimensional current structure in the Dutch coastal zone. Neth J Sea Res 25:45-55

Van Luijn F, Boers PCM, Lijklema L (1996) Comparison of denitrification rates in lake sediments obtained by $\mathrm{N}_{2}$ flux method, the ${ }^{15} \mathrm{~N}$ isotope paring technique and the mass balance approach. Water Res 30:893-900

Van Straaten LMJU, Kuenen PH (1957) Accumulation of finegrained sediments in the Dutch Wadden Sea. Geol en Mijnb 19:319-354

Van Straaten LJMU, Kuenen PH (1958) Tidal action as a cause for clay accumulation. J Sedimentol Petrol 28:406-413

Verwey J (1952) On the ecology of cockle and mussel in the Dutch Wadden Sea. Arch néerl Zool 10:171-239 